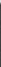

\author{
Resenhas
}

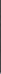




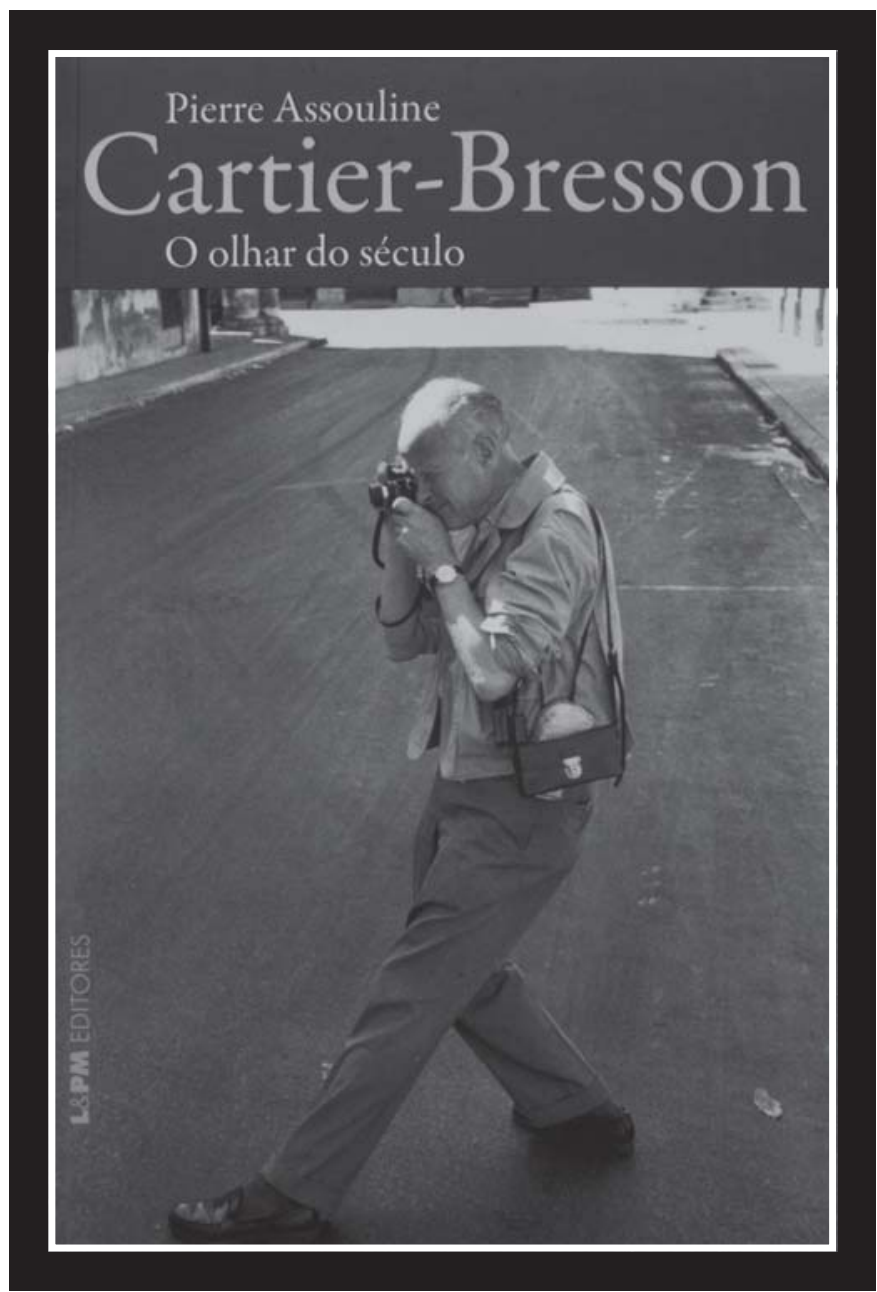

Cartier-Bresson: o olhar do século, de Pierre Assouline

(tradução de Julia da Rosa Simões). Porto Alegre, Editora L\&PM, 2008, 334 páginas. 


\section{O olhar do século}

\section{Paulo César Boni*}

Nascido em 22 de agosto de 1908, Henri Cartier-Bresson era filho de uma família abastada e com forte inclinação para as artes. Pode-se dizer que se tratava de uma família de pintores: de seu bisavô a seus tios, todos pintavam. A pintura estava em seu gene. Desde os cinco anos, apoiado principalmente pela mãe, freqüentava galerias, museus, ateliês e escolas de belas artes, para observação e aprendizado.

O jovem Henri recebeu a melhor educação formal possível no pós Primeira Guerra Mundial. Recebeu, mas não a assimilou por completo. Não por falta de capacidade intelectual, mas por não se adequar à rigidez da disciplina católica. Pierre Assouline, seu biógrafo e amigo pessoal, autor do livro Cartier-Bresson: o olhar do século, afirma que "a escola foi um dos períodos mais penosos de sua juventude”.

Independente de sua aversão à educação formal, Henri era um leitor assíduo de artistas e escritores considerados “desajustados” para a boa educação da elite parisiense. Cabulava aulas para - escondido em algum lugar do colégio Fénelon, de Paris, onde estudava - devorar livros “pouco aconselháveis”. Por algum tempo, contou com a conivência do supervisor do colégio que, admirador velado de autores desajustados, ofereceu seu gabinete para as leituras “pouco recomendadas” daquele jovem introspectivo, depois de surpreendê-lo absorto na leitura de poetas simbolistas, especialmente Rimbauld.

Nessa ocasião, 1924, estava com apenas 16 anos e já sabia do que gostava: pintura, música (por forte influência da mãe, dona Marthe, que era música e intelectual), cinema (mudo, à época) e literatura. Aos 19 anos, em 1927, passou a freqüentar o ateliê de André Lhote, em Paris, para aprender técnicas de retrato, gravura, esboço e, principalmente,

\footnotetext{
* Doutor em Ciências da Comunicação pela Universidade de São Paulo (ECA/USP). Coordenador do Mestrado em Comunicação da Universidade Estadual de Londrina.
} 
composição. Lhote era um obcecado pela geometria e influenciou decisivamente seu discípulo. Assouline chega a sugerir que o evangelho pessoal de Cartier-Bresson poderia começar com as seguintes palavras: "No princípio era a geometria..."

No início de 1928, foi para Cambridge, na Inglaterra, estudar no colégio Magdalen, “um dos lugares de onde se saí mais educado que instruído, ou o contrário, mas raramente os dois ao mesmo tempo”, adverte Assouline. Cambridge foi um período feliz de sua vida. Em 1930 voltou a Paris, onde estudou Marx, e também conheceu e passou a conviver com René Crevel e André Breton, defensores ardentes do movimento surrealista, que ganhava corpo na capital francesa. Por influência de Breton-e, claro, do surrealismo - Cartier Bresson "terá sempre o hábito de considerar o mundo, as pessoas e a vida de viés mais do que frontalmente”.

Por intermédio das novas companhias, conheceu o casal Gretchen e Peter Powel, americanos radicados em Paris, ricos e excêntricos, que mantinha consensual e “alegremente” um casamento aberto, tanto que o próprio Cartier-Bresson viveu um intenso caso de amor com Gretchen. Peter, fotógrafo ocasional, foi quem o iniciou na fotografia. A primeira câmera fotográfica da futura lenda da fotografia foi uma Krauss, adquirida de segunda mão.

O espírito aventureiro de Cartier-Bresson o levou a romper sua ligação com Gretchen e partir para um “batismo de fogo” na África. Para sobreviver, trabalhou como madeireiro, vendedor de bazar e, por fim, caçador. Quando não estava caçando, fotografava com sua Krauss e aplicava nas fotografias seus conhecimentos de pintura e geometria. Em sua estada na África, contraiu hematúria biliosa, uma grave doença causada por larvas de um parasita, um verme chamado bilhárzia. Desenganado pelos médicos, foi tratado com ervas por seu companheiro de caça, um marfinense de nome Doua.

Em 1931, aos 23 anos, Cartier-Bresson era um homem feito, que já havia passado por importantes “instantes decisivos”: a visão geométrica de mundo, o choque do surrealismo e a experiência de, por um triz (ou um milagre) não haver morrido. Assouline destaca que “como a ingratidão 
não é o seu forte, ele utilizará sua vida para homenagear discretamente Lhote, Breton e Doua”, pessoas importantes em sua formação e sua vida.

Já no início da década de 30, renunciou à pintura pela fotografia. Imagens de Eugène Atget e André Kertész o impressionavam. Mas foi uma única fotografia de Martin Munkacsi - aquela dos três adolescentes negros, de costas, tomada em contraluz, correndo para as águas do lago Tanganica, na África-que o influenciou decisivamente. “De repente, entendi que a fotografia podia fixar a eternidade no instante. Essa foi a única foto que me influenciou”, declarou Cartier-Bresson.

Segundo Assoline, Henri Cartier-Bresson tornou-se fotógrafo, de fato, em 1932, quando comprou uma câmera Leica, em Marselha. "É seu batismo de fogo”, diz o biógrafo. E complementa: “A Leica será seu objeto mitológico. Dela nunca mais se separará, seja no exterior, seja na intimidade.” A partir de então, destacou-se rapidamente com imagens publicadas em diversas revistas da Europa e dos Estados Unidos. A proliferação de revistas ilustradas e o rápido desenvolvimento de laboratórios profissionais de fotografia, nesse período, contribuíram para alavancar e acelerar seu sucesso como fotógrafo internacional.

Cartier-Bresson tornou-se um flâneur. Viajou pela Europa, foi morar no México, depois nos Estados Unidos. Sempre acompanhado de sua inseparável Leica, prestava atenção em tudo e tentava antever prováveis "momentos decisivos". Assouline diz que ele "ronda a surpresa a todo instante, mas nunca a espera. Seu único compromisso é com o acaso, que nunca marca hora”. Excelente fotógrafo; malsucedido laboratorista. O responsável pela qualidade de revelação de seus filmes e da ampliação de suas fotografias é o judeu alemão, “emigrado” para Paris, Pierre Gausmann.

Em 1936, aos 28 anos, Cartier-Bresson retornou a Paris. Tentou trocar a fotografia pelo cinema. Trabalhou como assistente faz-de-tudo de Jean Renoir, mas a experiência não foi bem sucedida. Casou-se com a bailarina javanesa Ratna Mohini. Tornou-se um homem mais “responsável”: saiu da casa da família e alugou um apartamento para o início da vida a dois. Mais que isso: arrumou um emprego fixo, como repórter fotográfico do recém fundado jornal esquerdista Ce Soir. Pouco tempo depois, aceitou 
o convite de uma instituição americana para dirigir, na Espanha, o documentário cinematográfico Victoire de la vie (Vitória da vida) sobre a resistência médica na Guerra Civil Espanhola. Em 1939, com o documentário pronto, voltou a Paris e retomou seu posto no Ce Soir, mas sequer “esquentou a cadeira”. Jean Renoir o convidou para ser seu assistente na produção do filme A regra do jogo.

No final da década, aconteceu o que a Europa toda temia: teve início a Segunda Guerra Mundial. Recrutado, Cartier-Bresson fazia parte de um time de fotógrafos e cinegrafistas que iria fotografar e filmar oficiais e soldados franceses para uma espécie de contrapropaganda nazista, arquitetada pelo governo francês. Missão que durou pouco: foi capturado e preso pelos alemães, em 1940, e trabalhou em campos de prisioneiros por quase três anos. Durante esse tempo, empreendeu três tentativas de fuga, só obtendo sucesso na última, em fevereiro de 1943. Passou a viver como foragido na própria França, tomada pelos alemães. Segundo Assouline, a guerra metamorfoseou o fotógrafo: "Ele aprendera coisas inacessíveis à compreensão dos homens livres.”

Nesse período de clandestinidade pessoal e profissional, em seu próprio país, aceitou o convite remunerado de Pierre Braun para fotografar grandes nomes da pintura e da literatura para uma série de monografias sobre os artistas franceses. $\mathrm{O}$ primeiro a ser fotografado foi o pintor Henri Matisse, que detestava ser fotografado. Cartier-Bresson ganhou sua confiança e amizade e produziu fotografias de sua intimidade profissional. Outro importante nome das artes plásticas fotografado foi Georges Braque, que lhe emprestou o livro A arte cavalheiresca do arqueiro zen, do alemão Eugen Herrigel. Este livro mudou, definitivamente, sua concepção de fotografia. Segundo seu biógrafo, ele "finalmente encontrou o manual ideal de fotografia, concebido para um espírito não-conformista como o seu”.

Na libertação da França, Cartier-Bresson estava nas ruas de Paris, fazendo fotojornalismo da melhor qualidade: algumas de suas mais importantes fotografias são desse momento de euforia e revanchismo contra os entreguistas, os colaboracionistas e as prostitutas que serviram aos alemães. 
Em 1946, foi para os Estados Unidos. O MoMa (Museu de Arte Moderna) de Nova Iorque estava organizando uma exposição "póstuma” em sua homenagem, mas o descobriu vivo, na França, antes de inaugurá-la. Lá, começou a trabalhar na revista Harper's Bazaar, onde conheceu e trabalhou com Truman Capote que, na década de 60, seria um dos criadores do new journalism.

Em maio de 1947, em Nova Iorque, associou-se a Robert Capa, David “Chim” Szymin e George Rodger e, juntos, fundaram a Magnum. A idéia da agência vinha sendo orquestrada há tempos por Capa, revoltado com o fato de ter que entregar seus negativos para quem o contratasse. A criação da Magnum significou um importante rompimento de fotógrafos com o vínculo empregatício. Eles passaram a trabalhar por conta e risco, produzindo suas reportagens e documentários sem patrão, sem pauta e, principalmente, sem deadline. Assouline escreve que "a agência não tem projeto comercial, mas um objetivo ético”. Só a partir de sua fundação, Cartier-Bresson assumiu ser um fotógrafo profissional. A fotografia passou, de fato, a ser o seu trabalho.

Em agosto do mesmo ano, embarcou para a Índia para fotografar o processo de descolonização da Ásia. Pela primeira vez, iria fotografar profissionalmente sem vínculo com nenhum jornal ou revista. Fotografou Mahatma Gandhi momentos antes de seu assassinato, e as solenidades de seu funeral. Importantes jornais e revistas americanas formaram fila em frente à sede da Magnum, ansiosos por publicar suas fotografias desse acontecimento que abalou a Índia e repercutiu pelo mundo todo. Cartier-Bresson morou por mais de um ano nesse país asiático, de onde se deslocou para temporadas de vivências e fotografias no Paquistão e na Birmânia. Em dezembro de 1948, atendeu a uma solicitação da Life e foi para a China, fotografar o fim do regime nacionalista, o Kuomitang, e de seu líder Chiang Kai-shek.

O ano de 1949 foi intenso. O fotógrafo viveu praticamente sediado na China, acompanhando as repercussões do fim do regime nacionalista e os primeiros passos do novo regime, o comunista. 
Dividiu-se entre Beijing, Shangai e Nanquim. Antes de retornar a Paris, no final do ano, passou por Hong Kong, Cingapura, Indonésia, Sumatra, Ceilão, Irã, Iraque e Síria.

Os acontecimentos de maior repercussão na Índia e na China fizeram que ele, além de fotografar, desenvolvesse o saudável hábito de tomar nota de tudo, com detalhista precisão de nomes, cargos, datas, locais e contextos. É dessa data sua recomendação expressa (carimbada atrás de cada fotografia) de que suas legendas não poderiam ser alteradas. Sua reportagem sobre a morte de Gandhi foi premiada nos Estados Unidos. Cartier-Bresson, apesar de avesso a rótulos, era então um dos maiores repórteres fotográficos e documentaristas imagéticos de seu tempo.

Assouline escreve que, na década de 50, Cartier-Bresson é "publicado, exposto, premiado, citado, comentado, admirado e invejado". Na casa dos 40 anos de idade, era um fotógrafo reconhecido e consagrado. Certa vez, ao entrar num clube de jazz famoso, o Dixieland, onde os Dukes tocavam, um músico virou-se para outro e, apontando CartierBresson, disse: "Aquele tipo é para a fotografia o que Louis Armstrong é para nós.”

Mas nem tudo eram flores na década de 50. AMagnum ia mal das pernas. Estava financeiramente à beira da falência, mal administrada pelo fanfarrão Robert Capa. Cartier-Bresson, que detestava administração, passou a exercer funções administrativas na tentativa de reerguê-la economicamente, sem perder a essência profissional, estética e ética que a caracterizava.

O pior ainda estava por vir. Em 1954, Robert Capa morreu ao pisar numa mina terrestre enquanto cobria a Guerra da Indochina. No mesmo dia (25 de maio de 1954), faleceu outro fotógrafo associado da Magnum, o suíço Werner Bischof, num acidente de carro na Cordilheira dos Andes. Dois anos mais tarde, em 1956, faleceu David "Chim" Szymin, baleado por um soldado egípcio no Canal de Suez. Capa e Chim eram amigos muito próximos e Cartier-Bresson ficou muito abalado com as perdas. 
Os anos 60 mudaram a história da humanidade. Foi uma década de intensas transformações. Cartier-Bresson também passou por profundas mudanças nesta década. Divorciou-se de Ratna, com quem estava casado havia 30 anos. Com ela, não teve nenhum filho. Demitiu-se da Magnum, em razão de não concordar com os novos rumos da agência, mais comerciais que estéticos. Desencantou-se parcialmente da fotografia, principalmente em razão do advento da cor na imprensa, dos rumos comerciais que os veículos de comunicação tomaram e, claro, da ascensão e efervescência da televisão, que exerceu imensurável fascínio sobre a população que, por conta dessa novidade, deixou de enxergar a fotografia com a atenção e magnitude que ela merecia. Na década seguinte, ele abandonou profissionalmente a fotografia (mas continuou fotografando seu lar, a família e alguns amigos até o fim da vida) para se dedicar novamente aos desenhos e à pintura.

Antes disso, porém, fotografou intensamente a França no final da década de 60. Esteve presente, com sua Leica e seu olhar jornalístico e humanista, nos acontecimentos que agitaram Paris, em 1968. Mais uma vez, alguns críticos - ou invejosos - disseram que ele teve sorte. A fama de "sortudo" o acompanhou desde o início da carreira, ainda nos anos 30, quando fotografou uma de suas obrasprimas: um homem saltando uma poça de água, atrás da Gare SaintLazare. A composição desta fotografia foi considerada de "perfeição gráfica”. A fama aumentou depois que fotografou o Mahatma Gandhi momentos antes de ser assassinado. Foi ele também que fez a última imagem do fotógrafo Alfred Stieglitz vivo. E a de Marcel Duchamp. E a de William Faulkner... Por último as barricadas de Paris...

Sorte?! O próprio Cartier-Bresson, ironicamente, costumava dizer que era um fotógrafo de sorte quando se cansava de dar explicações sobre suas fotografias. Mas seu preparo de toda uma vida - artes plásticas, geometria, literatura, e a incansável busca em entender a humanidade - depõe no sentido contrário. Ele não era um apertador de botão. Era, antes de tudo, uma pessoa com convicções e retidão de 
caráter; um autodidata com forte formação humanista, artística e crítica, que fotografava.

Cartier-Bresson entrou nos anos 70 com uma nova esposa, a fotógrafa Martine Franck, 30 anos mais nova que ele, com quem teve uma filha, Melanie. Mais dedicado à família, ficava mais em casa e fez uma opção clara e definitiva à pintura. Passou a renegar a fotografia. Recebeu muitas críticas dos pares. Assouline escreve que: "Nas conversas entre fotógrafos, o nome de Cartier-Bresson, antes evocado com a admiração devida a um mito vivo, agora é associado à traição. Ele é acusado de cuspir no prato que comeu."

Ele sempre foi uma pessoa “difícil”, mas suas dificuldades de convivência nos campos social e profissional se tornaram mais evidentes nesse período de sua vida. Cartier-Bresson não engolia a seco; não tinha meias-palavras, falava o que pensava. Às vezes, chegava a ser indelicado. Tinha suas convicções e delas não abria mão. Quase sempre era inflexível e fazia prevalecer seu modo de pensar. Era avesso a assédio, a puxa-saquismos, a elogios, a entrevistas, à televisão.

Assouline terminou seus escritos quando o fotógrafo ainda era vivo. Falava dele em vida. E preferiu deixar os tempos verbais todos no presente. Depois de sua morte, em 3 de agosto de 2004 (um ano trágico para a fotografia, aliás, pela morte de outros grandes fotógrafos, como Helmut Newton e Richard Avedon ), escreveu mais cinco ou seis páginas para “atualizar" os leitores. O livro é resultado de conversas e trocas de correspondência que o biógrafo manteve com o fotógrafo durante cinco anos e de centenas de horas de pesquisas nos acervos pessoais de Cartier-Bresson e na agência Magnum. Assouline confessa que teve muitas dificuldades para escrever sobre uma pessoa tão complexa, enigmática e genial. Antes de conhecê-lo pessoalmente, o autor se confessava um grande admirador de sua obra; depois de conhecê-lo sua admiração extrapolou o profissional e enveredou também pelo pessoal. Na introdução do livro, intitulada Quando o herói se torna um amigo, essa relação de respeito e admiração fica muito explícita. 
O livro é ótimo, muito bem escrito. Obedece a um caráter didático cronológico e traz muitas informações sobre a vida e obra de Henri CartierBresson, considerado pela maioria dos pares como o maior fotógrafo do século XX. Mesmo sem querer, e sem admitir, Cartier-Bresson influenciou - e continua influenciando - gerações de fotógrafos. A obra de Assouline preenche um vácuo de informações seguras - de fonte primária - e confiáveis sobre o francês que teve o olhar mais artístico, jornalístico, crítico e humano do século XX. 